\title{
PENINGKATAN LITERASI PERBANKAN SYARIAH BAGI PELAJAR SEKOLAH DI DESA BONTOLANRA TAKALAR
}

\author{
Niken Probondani Astuti ${ }^{1}$, Nurlaely Razak ${ }^{1}$, Dharmawati Djaharuddin ${ }^{1}$
}

\author{
Keywords : \\ Literasi Perbankan Syariah \\ Sosialisasi \\ Pelajar sekolah

\section{Corespondensi Author} \\ ${ }^{1}$ Manajemen, STIEM Bongaya \\ J1. Mapaodang \\ Email: nikenprobondani@gmail.com
}

\section{History Artikel}

Received: April 2019

Reviewed: April 2019

Revised: Mei 2019

Accepted: Juni 2019

Published: Juni 2019

\begin{abstract}
Abstrak. Kegiatan pengabdian kepada masyarakat ini dilaksanakan sebagai upaya untuk mengedukasi perbankan syariah pelajar Sekolah Menengah Atas melalui kegiatan literasi perbankan syariah. Hal ini dilatarbelakangi dengan kenyataan bahwa kegiatan edukasi yang dilakukan selama ini untuk meningkatkan literasi keuangan syariah masih belum tersosialisasi dengan baik dan belum bisa menyentuh pelajar sekolah khususnya didaerah pedesaan.

Sasaran pengabdian ini adalah pelajar sekolah SMA Nursya Galesong di Takalar. Materi yang akan disampaikan adalah pengenalan lembaga perbankan syariah. Kegiatan pengabdian akan dilaksanakan dalam bentuk sosialisasi. Kegiatan pengabdian telah dilaksanakan dalam beberapa tahap; koordinasi persiapan pelaksanaan, pelaksanaan kegiatan edukasi, dan kegiatan evaluasi kegiatan. Kegiatan pengabdian diikuti 37 pelajar. Kegiatan pengabdian kepada masyarakat dapat meningkatkan literasi keuangan syariah peserta. Hal ini ditunjukkan dengan semakin pahamnya peserta mengenai perbedaan bank syariah dan bank konvensional, konsep dasar keuangan syariah dan akad-akad yang digunakan untuk pengembangan produk lembaga keuangan syariah.
\end{abstract}

(i) This work is licensed under a Creative Commons Attribution

4.0 International License

\section{Pendahuluan}

\section{A. Analisis Situasi}

Sudah seperempat abad tiang sistem syariah terpancang di Indonesia yang ditandai dengan kehadiran bank syariah pertama pada tahun 1991, yaitu Bank Muamalat. Kampanye Nasional (Kamnas) Ekonomi Syariah 2016 diadakan untuk mengkampanyekan ekonomi syariah secara langsung kepada masyarakat luas dan diharapkan semakin banyak kalangan yang mengenal dan menerapkan sistem ekonomi syariah dalam tatanan kehidupannya.

Salah satu wajah besar dari ekonomi syariah adalah keuangan syariah. Sektor inilah pula yang paling dekat dengan masyarakat namun sayangnya masih terdapat gap antara literasi dan inklusi keuangan syariah ini.

Meskipun pemerintah telah menerbitkan banyak regulasi untuk mendukung pengembangan keuangan syariah, tantangan paling besar yang dihadapi oleh para pelaku industri ini adalah minimnya pengetahuan masyarakat mengenai keuangan syariah itu sendiri.

Menurut survei Otoritas Jasa Keuangan (OJK) pada 2016, menunjukkan 67,8 persen masyarakat yang telah menggunakan produk dan layanan keuangan syariah, namun hanya 29,7 persen masyarakat yang well literate. Indeks literasi dan 
inklusi keuangan khususnya syariah untuk masyarakat pedesaan menunjukkan nilai yang semakin rendah, yaitu hanya 23,9 persen masyarakat yang well literate dengan tingkat inklusi keuangan sebesar 63,2 persen [1]. Potensi perkembangan lembaga perbankan syariah yang besar belum dapat dioptimalkan oleh para pemangku kepentingan. Salah satu penyebabnya adalah rendahnya literasi keuangan syariah masyarakat Indonesia. Istilah-istilah mengenai perbankan syariah masih sulit untuk dikenali masyarakat umum.

Literasi keuangan terhadap lembaga dan produk keuangan syariah ini penting dilakukan karena dalam beberapa riset dunia mengungkapkan, dengan tingginya indeks literasi keuangan akan mendongkrak pertumbuhan perekonomian suatu negara. Suatu masyarakat yang telah memahami keuangan dengan segala aspeknya dapat meningkatkan kesejahteraan hidupnya dan dengan demikian akan meningkatkan pertumbuhan ekonomi suatu Negara. Kegiatan pengabdian untuk peningkatan literasi keuangan syariah bagi guru-guru Taman Pendidikan Alquran telah dilakukan oleh Kardoyo [2] Literasi keuangan masih rendah dikalangan guruguru. Setelah diadakan sosialisasi tingkat pemahaman guru-guru tentang perbankan syariah semakin baik. Diharapkan dengan bertambahnya pengetahuan guru-guru TPA mengenai perbankan syariah maka murid-murid TPA bisa lebih memahami mengenai perbankan syariah sehingga tingkat literasi keuangan semakin meningkat.

Otoritas Jasa Keuangan (OJK) sudah menyiapkan beberapa strategi untuk mencapai target literasi dan inklusi keuangan syariah pada 2019 sebesar 75\% dari total penduduk Indonesia. Oleh karena itu regulator mikroprudensial ini akan lebih menyasar ke siswa dari mulai sekolah dasar sampai sekolah menengah atas. Alasannya karena siswa sekolah di Indonesia jumlahnya cukup besar yaitu 52 juta orang atau seperlima dari jumlah penduduk.[3]

Di Sulawesi Selatan literasi keuangan syariah masih dibawah nasional sekitar $6.1 \%$ sedangkan indeks inklusi diatas nasional $13 \%$ dengan pangsa pasar sekitar $6.27 \%$ per Oktober 2017.[4] Padahal potensi pengembangan perbankan syariah sangat besar selain memiliki penduduk yang mayoritas beragama Islami ,daftar tunggu haji terlama di Indonesia ada di Sulsel. Artinya semangat ibadah di sini sangat tinggi, Hanya saja informasi tentang produk bank syariah relatif rendah.

Takalar merupakan salah satu kabupaten di Sulawesi Selatan yang memiliki potensi kelautan sangat besar utamanya bagi penopang pertumbuhan ekonomi kota Makassar. Dengan jumlah penduduk 289.978 jiwa [5]. Rendahnya literasi keuangan syariah juga dialami di Takalar khususnya desa Bontolanra. Tidak banyak yang mengenal produk dan akad dari jasa yang ditawarkan oleh lembaga perbankan syariah yang sedang berkembang. Hal ini dibutkikan tidak banyak masyarakat mengenal produk dari perbankan syariah. Hal inio juga didukung dengan tidaka adanya lembaga bank syariah yang hadir di Takalar.

Kenyataan tersebut menjadi landasan bagi tim pengabdian masyarakat STIEM Bongaya untuk memberikan kontribusi terhadap edukasi dan sosialisasi dalam rangka meningkatkan literasi perbankan syariah, khususnya pelajar sekolah yang memegang peranan yang sangat penting karena akan dapat mengenalkan sejak dini kepada pelajar tentang perbankan syariah yang berkembang saat ini. Jika pengenalan sejak dini berhasil, maka masyarakat Indonesia akan lebih cepat memahami keberadaan lembaga keuangan syariah. Dan pada akhirnya akan menentukan pilihan pemanfaatan produk-produk dan jasa yang ditawarkan lembaga perbankan syariah yang ada.

\section{B. Permasalahan Mitra}

Dari analisis situasi diatas diperoleh permasalahan yang dihadapi mitra pengabdian adalah rendahnya literasi keuangan syariah di Takalar khususnya desa Bontolanra. Tidak banyak yang mengenal produk dan akad dari jasa yang ditawarkan oleh lembaga perbankan syariah yang sedang berkembang. Hal ini dibutkikan tidak banyak masyarakat mengenal produk dari perbankan syariah. Hal ini juga didukung dengan tidak adanya lembaga bank syariah yang hadir di Takalar 


\section{Metode}

\section{A.Tahapan Pelaksanaan}

Kegiatan pengabdian ini dilaksanakan melalui beberapa tahapan, sebagai berikut:

1) Kegiatan awal dan persiapan

Dilakukan oleh tim pengabdi dengan pihak SMA Nursya Galesong sebagai tempat pelaksanaan kegiatan untuk berkoordinasi awal pelaksanaan kegiatan. Hal yang dikoordinasikan diantaranya adalah tempat pelaksanaan kegiatan.

\section{2) Pelaksanaan Kegiatan}

Tujuan dari kegiatan ini adalah meningkatkan literasi keuangan bagi pelajar sekolah. Kegiatan yang dilakukan oleh tim pengabdi adalah dengan melakukan sosialisasi kepada pelajar sekolah mengenai lembaga keuangan syariah (khususnya perbankan syariah) dan menggunakan media yang menarik. Kegiatan sosialisasi dilanjutkan dengan kegiatan sharing dan diskusi mengenai materi yang telah disampaikan dan pengetahuan lainnya.

\section{3) Evaluasi kegiatan}

Tujuan dari kegiatan ini untuk diskusi dan evaluasi dari semua tahapan kegiatan yang telah dilakukan serta rencana kedepan kelanjutan dari kegiatan pengabdian ini. Evaluasi kegiatan pengabdian akan dilakukan setiap akhir tahapan kegiatan pengabdian dengan memberikan penilaian secara langsung (direct observation), yaitu diberlakukan pada sesaat setelah kegiatan pengabdian dilaksanakan. Harapannya akan dapat dilakukan perbaikan. Indikator keberhasilan pelaksanaan kegiatan pengabdian akan diukur dengan tingkat pemahaman peserta. Tolok ukur keberhasilan kegiatan ini dapat dilihat dari aspek kualitatif dan kuantitatif berikut ini:

(a) semua tahapan kegiatan pengabdian dapat terlaksana dengan baik;

(b) pernyataan kepuasan dari peserta dan pihakpihak yang terkait terhadap keseluruhan rangkaian kegiatan pengabdian

(c) sebesar $80 \%$ peserta yang diundang bisa hadir dalam setiap kegiatan pengabdian.

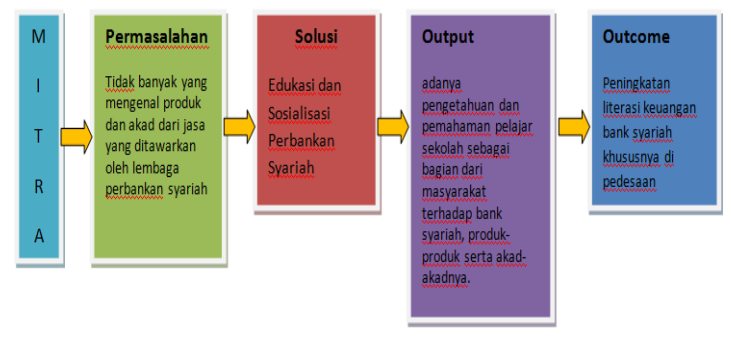

Gambar 1 Alur Metode Pelaksanaan

\section{B. Pelaksana dan Narasumber Kegiatan}

1. Niken Probondani Astuti, ST. MM \& Nurlaley Razak, S.Sos, MM (Pelaksana \& Narasumber - Dosen Tetap STIEM Bongaya)

2. KKLP STIEM Bongaya (Fasilitator)

\section{Hasil Dan Pembahasan}

Kegiatan pengabdian telah selesai dilaksanakan dengan baik dan lancar. Tahapan-tahapan kegiatan pengabdian diantaranya adalah sebagai berikut;

\section{1) Tahapan kegiatan perencanaan pengabdian}

Kegiatan perencanaan yang telah dilakukan adalah koordinasi dengan pihak sekolah SMA Nursya Galesong sebagai tuan rumah pelaksanaan kegiatan pengabdian. Tim pengabdi menyampaikan maksud dan tujuan kepada pihak sekolah SMA dan meminta izin serta arahan. Kemudian waktu dan tempat menjadi prioritas perencanaan serta identifikasi calon peserta kegiatan.

\section{2) Tahapan Kegiatan Pelaksanaan Pengabdian}

Kegiatan pengabdian dilaksanakan pada Kamis 29 Juli 2018 pukul 10.00 WITA di SMA Nursya Galesong. Kegiatan diikuti 37 pelajar. Pelaksanaan kegiatan pengabdian dibantu 2 orang mahasiswa, yaitu Sugiyanto dan Ummi Hidayah.

Kegiatan diawali dengan pembacaan ayat suci al quran, sambutan Kepala Sekolah SMA Nursya Galesong. Kegiatan dilanjutkan dengan paparan 
Niken Probondani Astuti, Nurlaley Razak, Dharmawati Djaharuddin. Peningkatan Literasi Perbankan Syariah bagi Pelajar Sekolah di Desa Bontolanra Takalar

materi oleh narasumbe. Narasumber menyampaikan materi tentang pengenalan lembaga keuangan syariah. Narasumber menyampaikan beberapa pertanyaan awal untuk mengetahu pemahaman awal dari peserta. Beberapa peserta telah memahami lembaga keuangan syariah (akad dan produk-produk perbankan syariah), sementara yang lainnya masih belum begitu mengenal. Narasumber kemudian menyampaikan materi yang telah disiapkan, diantaranya mengenai konsep dasar ekonomi syariah, perbedaan perbankan syariah dengan perbankan konvensional, prinsip keuangan Islam, dan akad-akad yang digunakan dalam transaksi lembaga keuangan syariah. Kegiatan dilanjutkan dengan tanya jawab. Salah satu peserta bertanya mengenai kasus aplikatif yang terjadi pada BMT. Dan narasumber memberikan penjelasan kembali.

Sebelum kegiatan pengabdian berakhir, narasumber mengajukan pertanyaan kepada peserta untuk mengetahui pemahaman mengenai materi yang disampaikan. Beberapa peserta telah cukup paham mengenai lembaga keuangan syariah secara dasar, khususnya akad-akad yang digunakan lembaga keuangan syariah. Namun demikian, perlu ditingkatkan lagi mengenai aplikasi akad-akad tersebut dalam produk perbankan syariah modern. Contohnya mengenai e-money, trading saham, dan lain sebagainya.

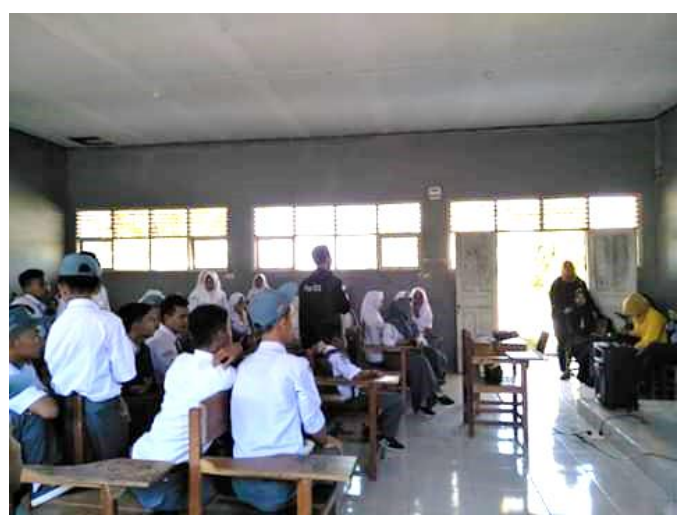

c) Tahapan kegiatan evaluasi pengabdian Tahapan kegiatan evaluasi dilakukan dengan tujuan;

(1) evaluasi proses pelaksanaan kegiatan pengabdian

(2) evaluasi peningkatan pemahaman peserta mengenai literasi keuangan syariah.

Evaluasi proses kegiatan pengabdian telah dilakukan dengan melihat jumlah peserta yang hadir, keseriusan peserta dalam mengikuti kegiatan, dan dukungan dari pihak sekolah SMA Nursya Galesong. Keseluruhan indikator menunjukkan bahwa kegiatan pengabdian ini dapat dilaksanakan dengan sukses dan lancar. SMA Nursya Galesong telah menunjukkan dukungan dengan menyediakan tempat dan fasilitas. Kepala Sekolah SMA Nursya Galesong memberikan sambutan yang hangat dan komunikatif kepada tim pengabdian dan berharap dapat menjadi tempat pengabdian di tahun berikutnya dengan topik yang berbeda. Keseriusan peserta dalam mengikuti dalam kategori baik.

Peningkatan literasi keuangan syariah khususnya bank syariah, sudah harus lebih diintensifkan dengan metode yang lebih sistematis dan terstruktur sehingga kedepan mampu meningkatkan persentase inklusi keuangan syariah. Kegiatan berikutnya akan dilaksanakan pelatihan yang lebih teknis yang diramu dalam bentuk pelatihan kelas

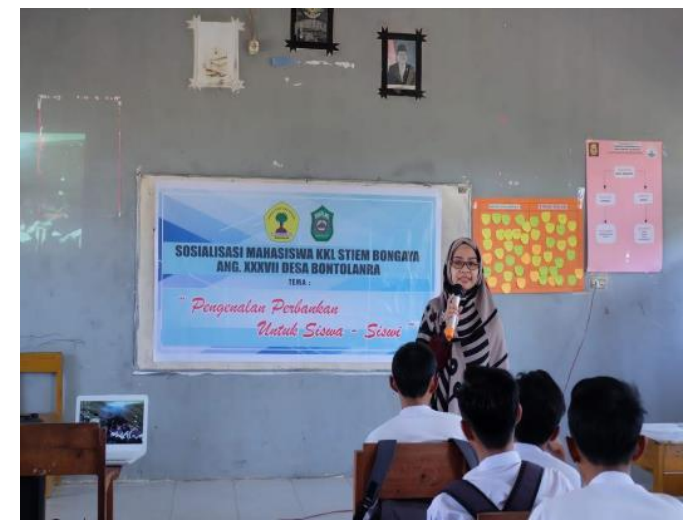

Gambar 2: Tim Memberikan Materi dalam Sosialisasi Perbankan Syariah di Bontolanra Takalar 
Niken Probondani Astuti, Nurlaley Razak, Dharmawati Djaharuddin. Peningkatan Literasi Perbankan Syariah bagi Pelajar Sekolah di Desa Bontolanra Takalar

\section{Simpulan Dan Saran}

Perkembangan industri perbankan syariah yang terus tumbuh ini perlu terus diimbangi dengan literasi keuangan syariah masyarakat. Sosialisasi bank syariah yang dilakukan kepada pelajar SMA Nursya Galesong di Bontolanra Takalar merupakan salah satu bentuk dukungan terhadap program literasi keuangan yang sedang digalakkan pemerintah. Antusias para pelajar SMA Nursya Galesong telah menunjukkan dukungan dengan menyediakan tempat dan fasilitas. Kepala Sekolah SMA Nursya Galesong memberikan sambutan yang hangat dan komunikatif kepada tim pengabdian dan berharap dapat menjadi tempat pengabdian di tahun berikutnya dengan topik yang berbeda. Keseriusan peserta dalam mengikuti dalam kategori baik.

\section{Saran}

Peningkatan literasi keuangan syariah khususnya bank syariah, sudah harus lebih diintensifkan dengan metode yang lebih sistematis dan terstruktur sehingga kedepan mampu meningkatkan persentase inklusi keuangan syariah. Kegiatan berikutnya akan dilaksanakan pelatihan yang lebih teknis yang diramu dalam bentuk pelatihan kelas

\section{Daftar Rujukan}

[1] http://makassar.tribunnews.com/2017/12/26/i ndeks-literasi-perbankan-syariah-di-sulselmasih-rendah.

[2] Kardoyo, Syamsu Hadi, Ahmad Nurkhin, Program Peningkatan Literasi Keuangan Syariah Bagi Guru Taman Pendidikan Quran (TPQ) di Kota Semarang, Jurnal Pengabdian Kepada Masyarakat Volume 24 No. 2, April - Juni 2018 p-ISSN: 0852-2715 | e-ISSN: 2502-7220

[2] http://makassar.tribunnews.com/2018/08/26/ minim-edukasi-pertumbuhan-perbankansyariah-alami-fluktuasi.

[3]https://keuangan.kontan.co.id/news/tingkatka n-literasi-ojk-sasar-anak-sma-hingga-sd
[4] BPS Kabupaten Takalar, 2016 [5]https://disnaker.makassar.go.id/2017/11/08/p otensi-pembangunan-kota-makassar/ 